\title{
Desain Passive U-Tube Tank pada Kapal Ikan Tradisional Tipe Kragan Guna Menurunkan Rolling Kapal
}

\author{
Farhan Abdul karim ${ }^{\left.l)^{*}\right)}$, Ahmad fauzan Zakki ${ }^{1)}$, Muhammad Iqbal ${ }^{1)}$ \\ ${ }^{1)}$ Departemen Teknik Perkapalan, Fakultas Teknik, Universitas Diponegoro \\ Jl. Prof. Soedarto, SH, Kampus Undip Tembalang, Semarang, Indonesia 50275
}

diajukan pada:07/03/18 direvisi pada $: 21 / 12 / 18 \quad$ diterima pada $: 07 / 02 / 19$

\begin{abstract}
Abstrak
Capsizing merupakan salah satu masalah yang terjadi pada kapal yang memiliki manuver tinggi. Hal tersebut berkaitan dengan gerakan rolling kapal dimana ketika nilai amplitudo rolling kapal terlalu besar maka akan menyebabkan terjadinya Capsizing. Gerakan ini akan berpengaruh terhadap kenyamanan dan keselamatan sebuah kapal. Dalam upaya menurunkan gerakan rolling pada kapal ikan tradisional tipe Kragan, penggunaan anti-roll jenis passive tank merupakan salah satu solusi yang ditawarkan untuk mengatasi masalah ini. Tujuan dari penelitian ini adalah untuk mengetahui besarnya pengurangan respon gerakan rolling kapal setelah menggunakan passive tank dan pengaruh konfigurasi ukuran pasiive tank. Harapannya hasil penelitian ini dapat bermanfaat untuk dijadikan rujukan dalam merancang passive tank bagi kapal nelayan di Indonesia. Pada penelitian ini, dilakukan analisa perbandingan penggunaan passive tank dengan variasi tinggi saluran dan lebar penampang. Pemodelan dilakukan dengan menggunakan software berbasis CAD yang kemudian dilakukan analisa perhitungan momen peredam untuk mendapatkan nilai Koefisien Damping yang mana digunakan untuk peredam tambahan pada analisa gerakan rolling kapal menggunakan software berbasis CFD dan Metode Panel. Hasil penelitian ini menunjukan bahwa kapal dengan penambahan passive tank Model $G$ memiliki respon momen redam dan Koefisien Damping yang paling baik dan dapat mengurangi nilai RMS rolling kapal sebesar 26,5\% dengan nilai RMS Rolling sebesar 2,69 Deg yang memenuhi standar kriteria seakeeping Nordforsk untuk kapal ikan.
\end{abstract}

Copyright $\odot$ 2018, KAPAL, 1829-8370 (p), 2301-9069(e)

Kata Kunci : Capsizing, Rolling, Seakeeping, Kapal ikan, Anti-Roll, Passive Tank

\section{PENDAHULAN}

Indonesia secara geografis merupakan sebuah negara kepulauan dengan dua pertiga luas lautan lebih besar dari pada luas daratan dan setidaknya memiliki 13.466 pulau yang berada di wilayah kelautan Indonesia. Kapal merupakan salah satu transportasi yang berperan penting dalam menunjang akses pulau-pulau di Indonesia serta digunakan dalam berbagai aspek seperti perdagangan maupun industri. Namun dalam

\footnotetext{
*) Penulis Korespondensi :

Email : farhanabdulkarim7@gmail.com
}

beberapa tahun terakhir tercatat data statistik kecelakaan kapal di Indonesia sebanyak 439 kasus sepanjang tahun 2015 hingga 2016, dimana diantaranya terjadi 56 kasus kecelakaan terbaliknya (Capsizing) kapal [1].

Gerakan rolling merupakan salah satu fenomena dari olah gerak kapal, dimana ketika amplitudo gerakan rolling besar, maka akan dapat menimbulkan capsizing.[2].

Kapal ikan merupakan salah satu kapal yang membutuhkan tingkat kestabilan yang relatif tinggi dibandingkan dengan kapal lainya. Hal ini dikarenakan pada saat beroperasi dalam 
penangkapan ikan membutuhkan kemampuan manuver yang baik dan tidak jarang berada dalam cuaca yang ekstrim sehingga cenderung lebih rentan terhadap terjadinya rolling secara berlebih [3]. Salah satu solusi dalam meminimalisir terjadinya rolling pada kapal pada umumnya adalah dengan penambahan system anti-rolling pada kapal.

Anti-rolling merupakan suatu mekanisme stabilisasi gerakan rolling yang digunakan di dalam struktur kapal [4]. Terdapat jenis antirolling diantaranya active fins, passive tanks, active tanks dan bilge keel. Passive tank merupakan salah satu jenis anti-rolling yang pada prinsipnya memanfaatkan aliran fluida[5].

Pada penelitian sebelumnya telah dilakukan kajian penggunaan anti-roll jenis fin stabilizer dan bilge keel, dengan hasil berupa persentase peredam roll dengan fin stabilizer adalah sebesar $75 \%$ [2] dan dengan ditambahkanya bilge keel adalah sebesar $4,42 \%$ [6].

Dalam perkembanganya, kapal ikan tradisional di Indonesia telah menggunakan antiroll jenis bilge keel dan active fins. Untuk bilge keel secara teknis dianggap relatif kurang efisien dibandingkan dengan passive tank, serta untuk active fins yang memiliki nilai rata-rata peredam roll yang lebih tinggi dianggap kurang cocok dari segi ekonomi untuk diterapkan pada kapal ikan tradisional karena jauh lebih mahal dalam pembelian dan perawatanya dibandingkan dengan passive tank $[7,8]$. Oleh karena itu perlu adanya penelitian lebih lanjut mengenai desain anti-roll jenis passive tank yang dipasang pada lambung kapal ikan, dengan harapan tercapainya performa kapal ikan yang lebih baik.

Berdasarkan landasan tersebut agar mengetahui pengaruh passive tank dengan variasi tinggi saluran dan lebar penampang yang dipasang pada kapal ikan terhadap gerak rolling kapal, maka perlu dilakukan analisa lebih lanjut. Analisa yang dilakukan berupa pembuatan model kapal dan passive tank menggunakan bantuan software berbasis $\mathrm{CAD}$, analisa perhitungan respon momen redam passive tank serta analisa gerakan rolling kapal menggunakan bantuan software berbasis CFD dan Metode Panel.

Adapun tujuan dari peneitian ini adalah untuk menghitung besarnya pengurangan respon gerakan rolling kapal setelah menggunakan passive tank. Selain itu, penelitian ini bertujan untuk mendapatkan pengaruh konfigurai ukuran pasiive tank seperti tinggi saluran dan diameter passive tank terhadap koefisien redam rolling yang dihasilkan. Sedangkan manfat dari hasil penelitian ini adalah dapat dijadikannya rujukan dalam merancang passive tank bagi kapal nelayan di Indonesia.

\section{METODE}

Penelitian ini menggunakan sampel kapal ikan tradisional tipe Kragan dengan penambahan Passive Tank yang divariasikan pada variabel ketinggian saluran dan lebar penampang Passive Tank. Data teknis berupa ukuran utama kapal dan Passive Tank, Linesplan kapal serta Variasi model Passive Tank yang dapat dilihat pada Tabel 1,2,3 dan Gambar 1,2.

Tabel 1. Ukuran utama kapal

\begin{tabular}{ccc}
\hline No & Dimensi & Skala Penuh \\
\hline 1 & LOA & $49,50 \mathrm{~m}$ \\
2 & $\mathrm{~B}$ & $13,95 \mathrm{~m}$ \\
3 & $\mathrm{H}$ & $5,85 \mathrm{~m}$ \\
4 & $\mathrm{~T}$ & $4,725 \mathrm{~m}$ \\
5 & Vs & 9 knot \\
\hline
\end{tabular}

Tabel 2. Ukuran Utama Passive Tank

\begin{tabular}{ccc}
\hline No & Dimensi & Skala Penuh \\
\hline 1 & Tinggi Fluida (hr) & $1,40 \mathrm{~m}$ \\
2 & Total tinggi (ht) & $2,60 \mathrm{~m}$ \\
3 & Lebar saluran (wd) & $5,30 \mathrm{~m}$ \\
4 & Jarak ke Midship (rd) & $0 \mathrm{~m}$ \\
5 & Panjang (s) & $4 \mathrm{~m}$ \\
\hline
\end{tabular}

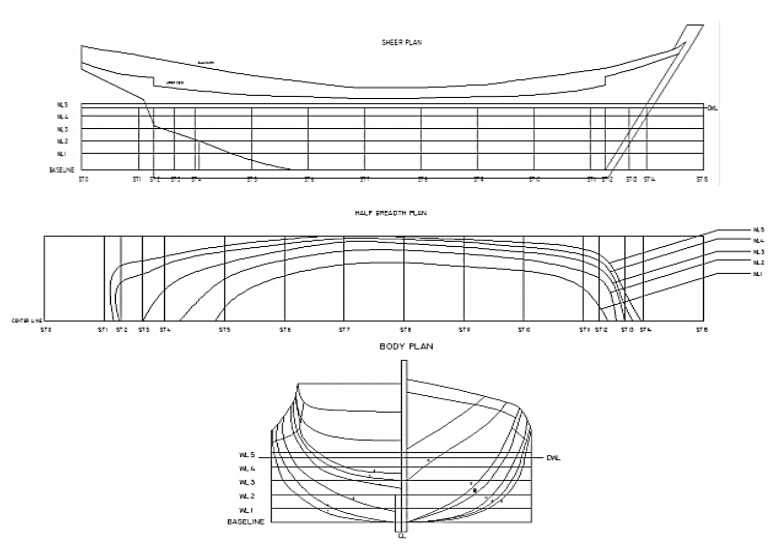

Gambar 1. Linesplan Kapal

Tabel 3. Variasi Model Passive Tank

\begin{tabular}{ccc}
\hline $\begin{array}{c}\text { Model Passive } \\
\text { Tank }\end{array}$ & $\begin{array}{c}\text { Tinggi } \\
\text { saluran } \\
\text { (hd) }\end{array}$ & $\begin{array}{c}\text { Diameter } \\
\text { (wr) }\end{array}$ \\
\hline $\mathrm{E}$ & $0,65 \mathrm{~m}$ & $1,5 \mathrm{~m}$ \\
$\mathrm{G}$ & $1 \mathrm{~m}$ & $0,75 \mathrm{~m}$ \\
\hline
\end{tabular}




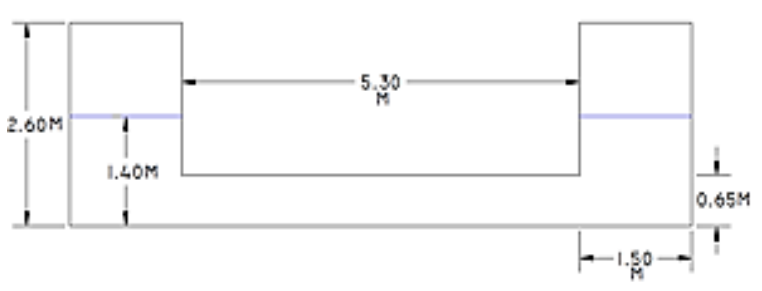

(a)

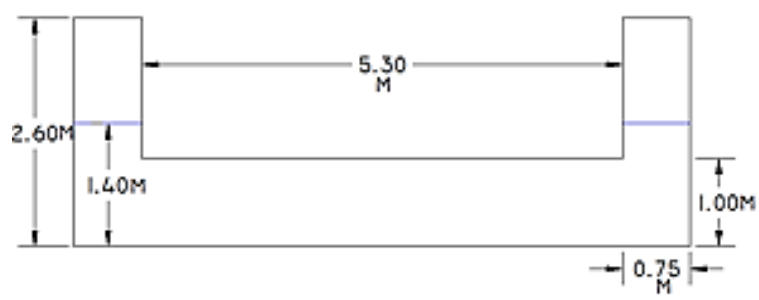

(b)

Gambar 2. Model Passive Tank: (a) Model E 2D, (b) Model G 2D

Untuk mendapatkan pengaruh variasi tinggi saluran dan penampang Passive Tank terhadap Rolling kapal , penelitian ini dilakukan dengan tahapan sebagai berikut: Tahap pertama adalah membuat model kapal dan Passive Tank dimana untuk menentukan ukuran utama Passive Tank digunakan rasio ukuran penelitian sebelumnya, yang kemudian didapatkan ukuran utama serta variasi pada tinggi saluran dan lebar penampang Passive Tank.

Tahap kedua adalah perhitungan momen peredam Passive Tank menggunakan bantuan software berbasis CFD yang kemudian dilakukan olah data untuk mencari nilai slope dengan metode regresi yang merupakan nilai koefisien redaman Passive Tank.

Tahap ketiga adalah analisa olahgerak kapal (Rolling) menggunakan software berbasis metode panel. Pada tahap ini dilakukan Analisa perhitungan RAO Roll kapal sebelum dan sesudah adanya penambahan Passive Tank, dimana hasil perhitungan koefisien redaman dijadikan inputan dalam proses perhitungan ini.

Pada analisa ini menggunakan Spektrum gelombang parameter ITTC dengan ketinggian gelombang sebesar 1 meter dan Wave Direction $90^{\circ}$.

Tahap keempat yaitu mengolah data hasil analisa olah gerak kapal yang berupa RAO Roll menjadi RMS (Root mean square).

Tahap kelima yaitu membandingkan hasil analisa dengan adanya penambahan Passive Tank terhadap standar kriteria seakeeping Nordforsk untuk kapal ikan.

Tahap kelima yaitu penarikan kesimpulan pengaruh variasi tinggi saluran dan lebar penampang Passive Tank terhadap nilai Rolling kapal.

\section{HASIL DAN PEMBAHASAN}

\subsection{Model 3D Kapal dan Passive Tank}

Pembuatan model menggunakan software berbasis CAD dengan hasil sebagaimana terdapat pada Gambar 3. Gambar 3 (a) adalah model 3D kapal dan Gambar 3 (b) adalah model 3D Passive Tank.

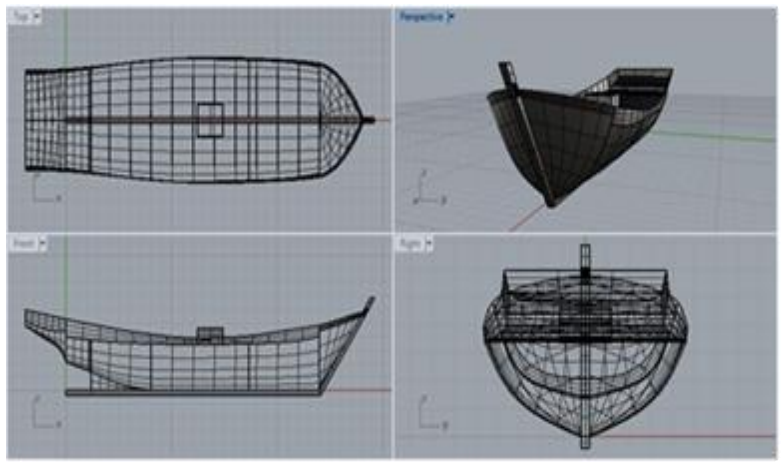

(a)

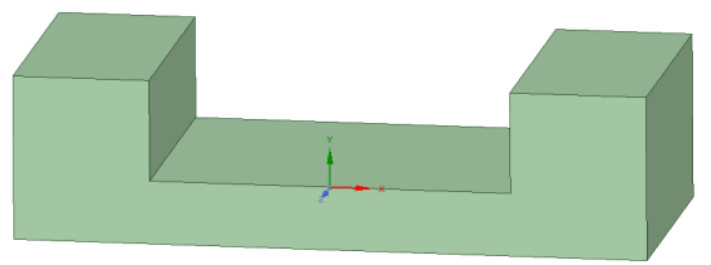

(b)

Gambar 3. Pembuatan model : (a) Model 3D kapal, (b) Model 3D Passive Tank

Model ini selanjutnya akan dieksport kedalam bentuk file .iges yang kemudian dijalankan pada software CFD dan metode panel untuk dilakukan proses analisa selanjutnya.

\subsection{Koefisien Peredam Passive Tank}

Pada tahap Geometry diawali dengan import model Passive Tank ke software berbasis CAD, dalam penelitian kali ini menggunakan Ansys CFX v.18.1. Langkah selanjutnya yaitu tahap Meshing, hal ini dilakukan dengan tujuan untuk memberikan kerapatan yang lebih baik pada proses analisa dan hasil yang lebih akurat (Gambar 4).

Langkah berikutnya adalah Setup untuk menentukan Default domain modified, Expression, Initialization dan Solver [9]. Pada tahap ini dilakukan proses Running model sebanyak 3 kali dengan kecepatan sudut yang berbeda agar dapat dilakukan perhitungan koefisien redam menggunakan metode Regresi. 
Kecepatan sudut yang dignakan dalam penelitian ini terdapat pada Tabel 4. Sedangkan hasil simulasi CFD terdapat pada Gambar 5.

Tabel 4. Nilai angular velocity

\begin{tabular}{ccc}
\hline No & Derajat/detik & Radian/detik \\
\hline 1 & 6 & 0,10500 \\
2 & 3 & 0,05260 \\
3 & 1 & 0,01745 \\
\hline
\end{tabular}

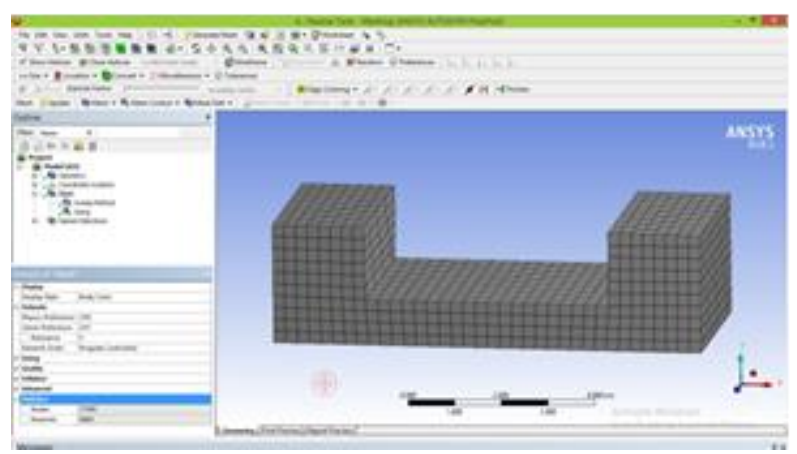

Gambar 4. Model Meshing Passive Tank

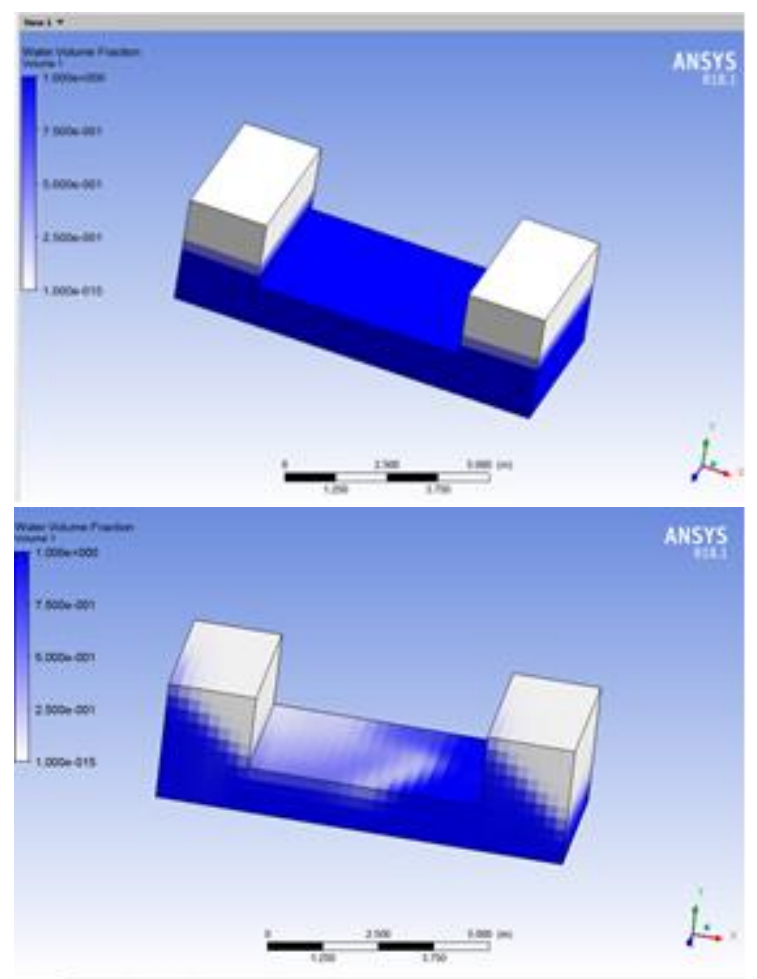

Gambar 5. Ilustrasi Running Perhitungan Momen

Peredam pada software Ansys CFX

Tabel 5. Nilai momen peredam Passive Tank

\begin{tabular}{ccccc}
\hline \multirow{2}{*}{ Model } & $\begin{array}{c}\text { Kecepatan } \\
\text { sudut Roll }\end{array}$ & \multicolumn{3}{c}{ Momen Peredam (N.m) } \\
& $\mathbf{X}$ & $\mathbf{Y}$ & $\mathbf{Z}$ \\
\hline $\mathrm{E}$ & 6 Deg/s & 292800 & 505182 & -81846.8 \\
& 3 Deg/s & -285632 & 510684 & 140702 \\
& 1 Deg/s & -549319 & 198971 & 776.421 \\
$\mathrm{G}$ & 6 Deg/s & 295828 & 505292 & -112009 \\
& 3 Deg/s & -290075 & 508307 & -62426.8 \\
& 1 Deg/s & -550328 & 200097 & -30522.5 \\
\hline
\end{tabular}

Tabel 5 menunjukkan nilai momen peredam yang dihasilkan pada kecepatan sudut yang berbeda-beda. Selanjutnya, tahapan terakhir dalam proses ini yaitu perhitungan koefisien redam menggunakan metode Regresi Linear.

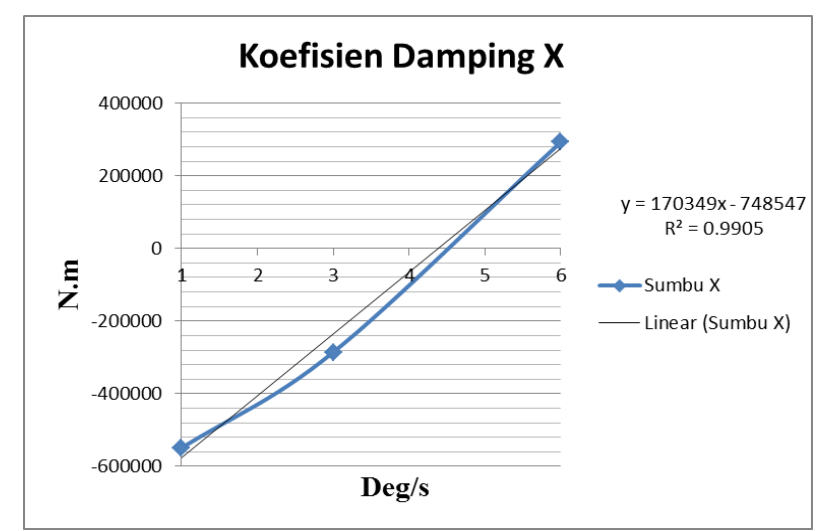

Gambar 6. Perhitungan Koefisien Damping

Gambar 6 adalah perhitungan koefisien redam Model E. Dari 3 kecepatan sudut yang menghasilkan momen redam yang berbeda-beda, dapat dihasilkan koefisien redamnya dengan menggunakan regresi linear. Dengan dilakukanya perhitungan menggunakan metode regresi maka dapat menentukan nilai Koefisien Damping sebagaimana yang terdapat pada Tabel 6 .

Tabel 6. Nilai Koefisien Damping Passive Tank

\begin{tabular}{|c|c|c|c|}
\hline \multirow{2}{*}{ Model } & \multicolumn{3}{|c|}{ Koefisien Damping (N.m/(deg/s)) } \\
\hline & $\mathbf{X}$ & $\mathbf{Y}$ & $\mathbf{Z}$ \\
\hline $\mathrm{E}$ & 170349 & 56263 & -21077 \\
\hline G & 204056 & 56141 & -16315 \\
\hline
\end{tabular}

\subsection{Olah Gerak Kapal}

Pada tahap Geometry diawali dengan import model kapal ke software berbasis metode Panel, dalam penelitian kali ini menggunakan Ansys Aqwa v.18.1. Langkah selanjutnya yaitu tahap Meshing, pada penelitian kali ini digunakan ukuran Meshing element sizing sebesar 1/82,5 LOA, hal ini dilakukan dengan tujuan untuk memberikan kerapatan yang lebih baik pada proses analisa dan hasil yang lebih akurat (Gambar 7).

Analisis olah gerak dihitung menggunakan software Aqwa v.18.1 dengan memasukan nilai damping passive tank yang kemudian dilakukan analisa gerakan rolling kapal dengan sudut gelombang $90^{\circ}$. Hasil simulasi gerakan rolling terdapat pada Gambar 8.

Pada kenyataannya, gelombang di laut adalah gelombang acak sehingga respon kapal terhadap gelombang reguler yang dinyatakan dalam RAO tidak dapat menggambarkan respon kapal pada 
keadaan sesungguhnya di laut. Untuk mendapatkan respon gerakan kapal terhadap gelombang acak dapat digambarkan dengan spektrum respon. Spektrum respon didapatkan dengan mengalikan spektrum gelombang [5]. Untuk perairan laut jawa, data yang digunakan dalam penelitian ini yaitu tinggi gelombang signifikan (Hs) $1 \mathrm{~m}$, dan dari data tinggi gelombang yang didapatkan lalu dicari nilai periode rata-rata (Tav) pada tabel sea state yaitu 3,2109 [5].

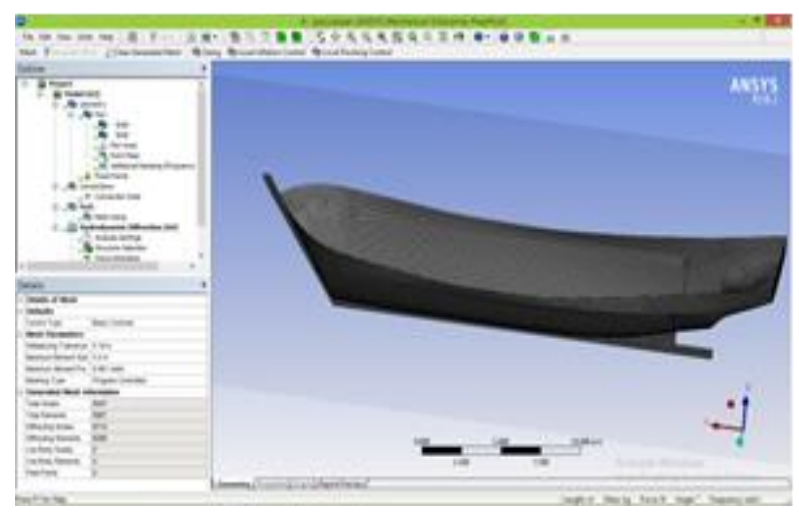

Gambar 7. Model Meshing Kapal

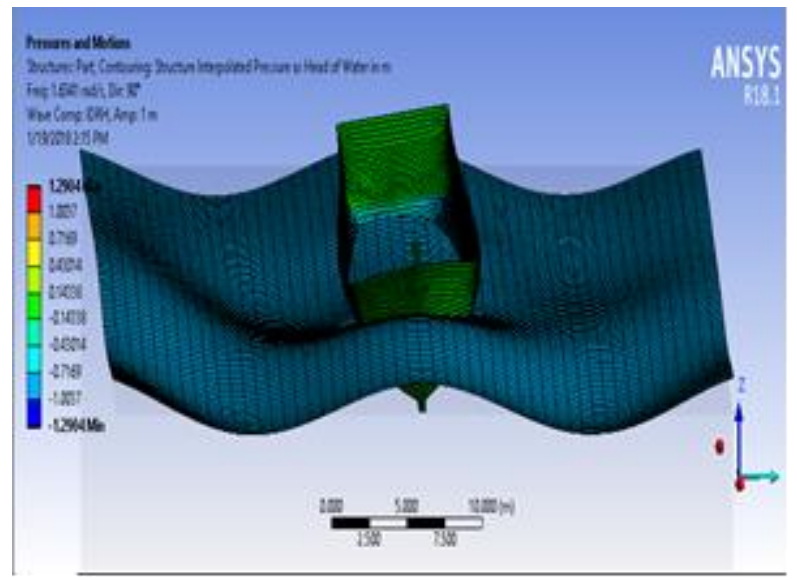

Gambar 8. Ilustrasi Gerakan Rolling kapal

\subsection{Respon Gerakan Rolling}

Hasil analisa olah gerak Rolling ini berupa Response Amplitudo Operator (RAO) Rolling kapal sebagaimana yang terdapat pada Gambar 9. Kemudian kondisi perairan tempat kapal beroperasi yang digambarkan dengan spektrum gelombang terdapat pada Gambar 10. Kurva RAO dan Spektrum Gelombang ini akan menghasilkan Spektrum Respons (Gambar 11) yang akar dari luasan di dalam kurvanya menghasilkan nilai Root Mean Square (RMS) Rolling kapal.

Gambar 9 adalah grafik RAO dari gerakan rolling kapal pada arah gelombang sisi kapal atau pada sudut $90^{\circ}$. Dapat dilihat bahwa puncak tertinggi RAO terdapat pada model original (tanpa passive tank) yang kemudian disusul oleh model E dan $\mathrm{G}$.

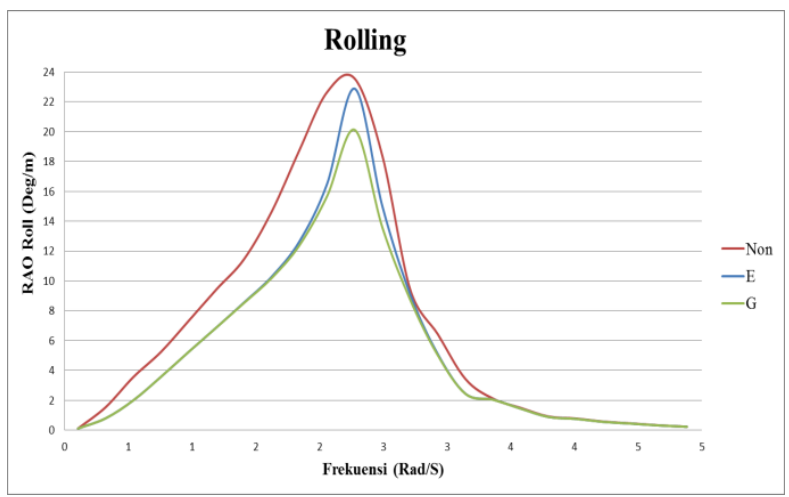

Gambar 9. Perbandingan RAO Rolling

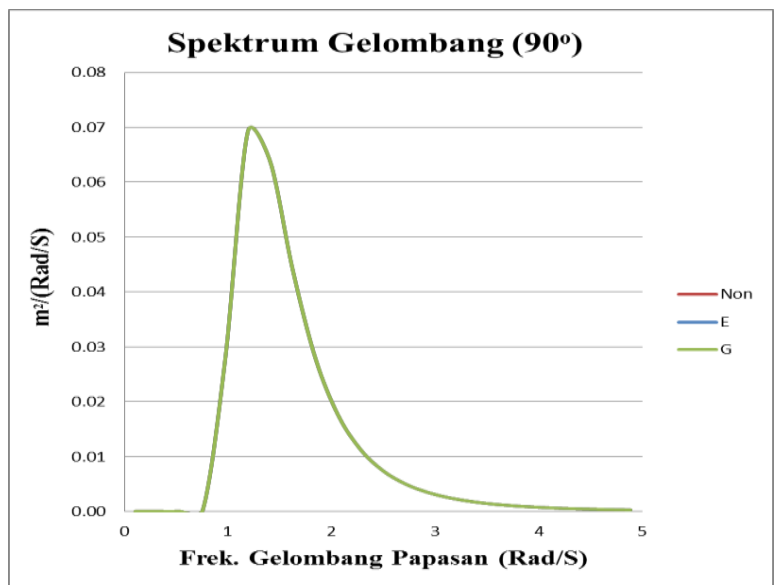

Gambar 10. Spektrum Gelombang pada Gelombang $90^{\circ}$

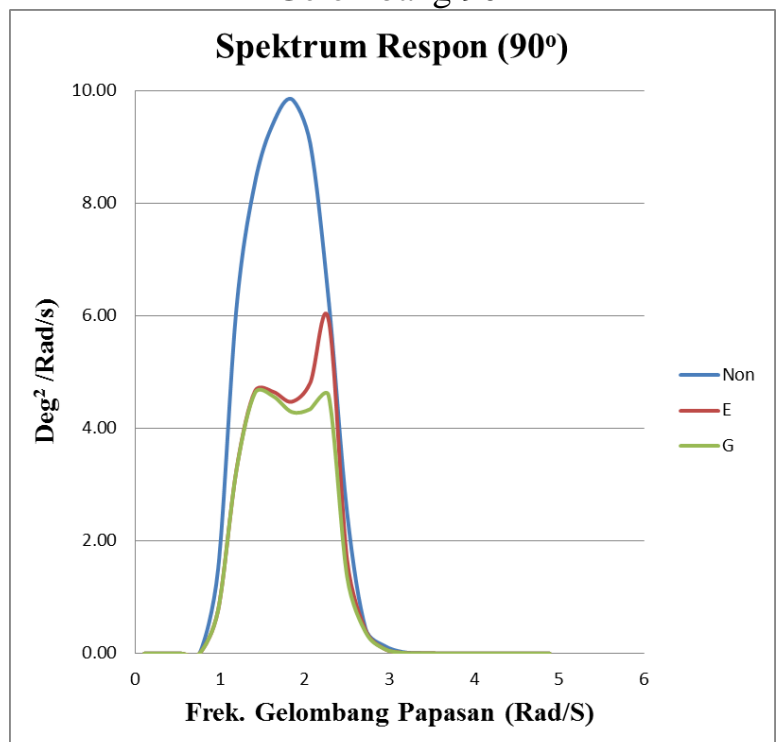

Gambar 11. Spektrum Respon pada Gelombang $90^{\circ}$

Perbedaan model $\mathrm{E}$ dan $\mathrm{G}$ adalah pada tinggi saluran dan diameternya, dimana pada model $G$ kedua nilai tersebut lebih besar dari model $\mathrm{E}$ (Tabel 3). Dengan tinggi permukaan air yang sama $(1,40 \mathrm{~m})$, hal ini menunjukkan bahwa 
volume air model G lebih banyak dari pada model E.

Spektrum gelombang dapat dilihat pada Gambar 10. Pada gambar 11 respon gerakan rolling yang dipresentasikan dengan kurva spektrum respon. Dari gambar tersebut terlihat bahwa luasan dibawah kurva antara kapal yang menggunakan passive tank dan yang tidak menggunakan berbeda signifikan. Akar dari luasan tersebut disebut dengan RSM merupakan respon gerak rolling kapal di gelombang acak.

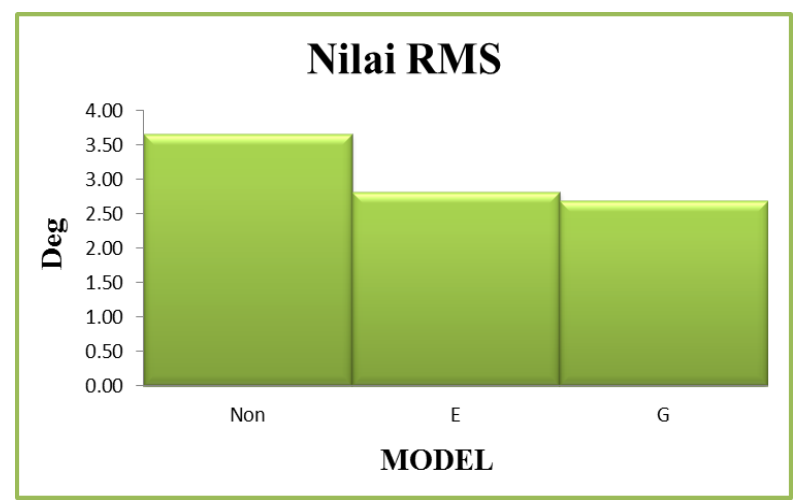

Gambar 12. Perbandingan RMS Roll

Tabel 7. Perbandingan Presentasi Momen Redam Passive Tank

\begin{tabular}{ccc}
\hline Model & $\begin{array}{c}\text { RMS Rolling } \\
\text { (Deg) }\end{array}$ & $\begin{array}{c}\text { Persentase Redam } \\
(\boldsymbol{\%})\end{array}$ \\
\hline Non & 3,66 & - \\
E & 2,83 & $-22,8$ \\
G & 2,69 & $-26,5$ \\
\hline
\end{tabular}

Akar kuadrat dari luasan kurva dari spektrum respon (RMS) disajikan pada Gambar 12 dan Tabel 7. Dapat dilihat bahwa kapal yang tidak menggunakan passive tank mempunyai RMS rolling sebesar $3,66^{\circ}$. Sebenarnya nilai RMS ini masih sesuai dengan kriteria standar gerakan respon rolling kapal menurut Nordforks [10] sebesar $6^{\circ}$. Sedangkan yang menggunakan passive tank berkurang menjadi $2,83^{\circ}$ pada Model E dan dan 2,69 pada Model G.

Hal ini membuktikan bahwa penggunaan passiive tank pada kapal dapat meredam gerakan rolling kapal lebih dari 20\% dibandingkan dengan yang tidak menggunakan.

Dari Tabel 7 dapat dilihat bahwa respon gerakan rolling model $\mathrm{E}$ dan $\mathrm{G}$ tidak terlalu signifikan. Namun Model $G$ lebih meredam gerakan rolling dari pada model E. Perbedaan konfigurasi tinggi saluran dan diameter passive tank dapat memberikan redaman rolling yang berbeda.

Pada penelitian ini Model $G$ dengan nilai tinggi saluran dan diameter yang lebih besar dari model E mampu lebih meredam gerakan rolling kapal dari model E dengan selisih sebesar 3,7\%

\section{KESIMPULAN}

Hasil penilitian ini menunjukkan bahwa kapal yang menggunakan passive tank (Model E dan Model G) mampu untuk meredam gerakan rolling sebesar 22,8 \% sedangkan Model G mampu meredam Roll sebesar 26,5\%.

Berdasarkan hasil tersebut, dapat disimpulkan bahwa pengaruh konfigurasi ukuran pasiive tank seperti penambahan tinggi saluran (hd) dan diameter passive tank (wr) akan terjadi penurunan nilai RMS Roll kapal.

\section{DAFTAR PUSTAKA}

[1] Apmi, 2016, Kajian Kecelakaan kapal di Indonesia sepanjang tahun 2015-2016.

[2] Herbowo, A., Chrismianto, D., dan Iqbal, M., 2017, Analisa Fin Stabilizer Terhadap Rolling Pada Kapal Ferry Ro-Ro 500 GT Dengan Metode CFD, Jurnal Teknik Perkapalan, 5(1): 130-136.

[3] Zarma, N., Zakki, A. F., dan Trimulyono, A., 2015, Studi Karakteristik Seakeeping Kapal Ikan Tradisional dan Modern, Jurnal Teknik Perkapalan, 3(1): 173-182.

[4] Taskar, B. U., DasGupta, D., Nagarajan, V., Chakraborty, S., Chatterjee, A., Sha, O. P., 2014, CFD aided modelling of anti-rolling tanks towards more accurate ship dynamics, Ocean Engineering Elsevier, 9(2014): 296-303.

[5] Winden, B., 2009, Anti Roll Tanks in Pure Car and Truck Carriers, Tesis, KTH Centre for Naval Architecture, Stockholm.

[6] Malik, M. I., Manik, P., dan Iqbal, M., 2016, Pengembangan Desain Geometri Lunas Bilga untuk Meningkatkan Performa Kapal Ikan Tradisional (Studi Kasus Kapal Tipe Kragan), Jurnal Teknik Perkapalan, 4(4): 748-757.

[7] 7. Aalto University School of Engineering, 2016, Control of Ship Motion, http://mycourse.aalto.fi>SD10Control(6/4/2017).

[8] Kula, K. S., 2015, An Overview of Roll Stabilizers and Systems For Their Control, The International Journal on Marine Navigation and Safety of Sea Transportation, 9(3): 405-414.

[9] Daalen, E.F.G. V., Gerrits, J., Veldman, A.E.P., 2000, Anti-Roll Tank Simulations With A Volume Of Fluid (VOF) Based 
Navier-Stokes Solver. Gronigen, The Netherlands.

[10] Nordforsk, "Seakeeping Criteria" 1897. 